\title{
Factors influencing cladoceran abundance and species richness in brackish lakes in Eastern Spain
}

\author{
A.J. Green ${ }^{1 *}$, C. Fuentes ${ }^{1,2}$, E. Moreno-Ostos ${ }^{3}$, S.L. Rodrigues da Silva ${ }^{3}$ \\ ${ }^{1}$ Estación Biológica de Doñana, Avenida de María Luisa s/n, Pabellón del Perú, 41013 Sevilla, Spain. \\ 2 Universidad de Alicante, Departamento de Ecología, Apdo 99, E-03080 Alicante, Spain. \\ 3 Instituto del Agua, Universidad de Granada, C/Ramón y Cajal, 4, 18071 Granada, Spain.
}

\begin{abstract}
We studied the Cladocera in four shallow brackish lakes at El Hondo and Salinas de Santa Pola in Mediterranean Spain from February 1999 to June 2000, sampling each month. We recorded five species : Daphnia magna, D. pulex, D. longispina, Simocephalus exspinosus and Moina brachiata. D. magna was the most abundant species and the only one present all year round. Total abundance of Cladocera varied significantly between wetlands and months, and was highest in the largest, deepest, least saline wetlands. For a given wetland and month, abundance increased at points of greater depth or lower salinity. Species richness of Cladocera was highest in those seasons and lakes where salinity was lowest, and in those seasons and lakes where cladoceran abundance was highest. These wetlands hold a particularly high number of waterbird species, but a very low number of Cladocera species. Ready dispersal via waterbirds does not appear to promote cladoceran diversity in this system, owing to local conditions such as high salinity. We suggest that the conservation value of wetlands for birds is not a good predictor of value for Cladocera.
\end{abstract}

Keywords : Alicante, Cladocera, Daphnia magna, depth, salinity, species richness.

\section{Introduction}

In the Mediterranean region, wetlands have largely been inventoried and protected on the basis of their importance for waterbirds (Martí \& del Moral 2002). On the other hand, studies of Cladocera and other zooplankton have often focussed on reservoirs or small ponds of relatively little value for waterbirds. It is important to establish whether a network of protected wetlands established with waterbird criteria is effective for the conservation of zooplankton, i.e. is value for birds and for zooplankton correlated? Cladocera are able to passively disperse between wetlands via birds (Figuerola \& Green 2002a), and it has been suggested that wetlands frequented by more migratory birds should hold a higher species richness of Cladocera (Green \& Figuerola 2005).

The great importance of wetlands in southern Alicante, eastern Spain for waterbirds has led to their pro-

* Corresponding author : E-mail: ajgreen@ebd.csic.es tection as two Ramsar sites (El Hondo and Salinas de Santa Pola, Bernués 1998). The Rotifera and Copepoda in El Hondo have been studied previously (Rodrigo et al. 2001, Armengol et al. 2002) but there are no previous studies of the Cladocera. In this study we quantify the abundance of Cladocera and compare the species present in four different wetlands during different parts of the annual cycle. We test the role of depth, conductivity and other factors in determining the observed patterns of abundance. We consider whether the importance of these wetlands for birds is reflected by a similar importance for microcrustaceans, and whether the high density of migratory birds coming from other wetlands has produced a high species richness of Cladocera via zoochory.

\section{Materials and methods}

\section{Study Sites}

El Hondo is a complex of mesosaline and polysaline semi-artificial wetlands (total 1,650 ha) in the south of 
Alicante province $\left(38^{\circ} 11^{\prime} \mathrm{N}, 00^{\circ} 45^{\prime} \mathrm{W}\right)$. Up to 42,000 migratory waterbirds use El Hondo in winter, $27 \%$ of which are Shoveller Anas clypeata, 20\% Coot Fulica atra and 14\% Pochard Aythya ferina (Martí \& del Moral 2002). El Hondo is a major breeding area for the globally threatened White-headed Duck Oxyura leucocephala and Marbled Teal Marmaronetta angustirostris as well as Pochard and other ducks (Martí \& del Moral 2003).

We studied the largest wetlands in El Hondo (Fig. 1, Table 1): Poniente reservoir, Levante reservoir and the Reserva pond. All three are eutrophic with periods of hypertrophy (Table 1). They are surrounded by dykes and canals and constructed on top of what was a large, natural wetland until 1920 (Viñals et al. 2001). Phragmites australis is the dominant emergent vegetation (Cirujano et al. 1995). Submerged vegetation is domi- nated by Potamogeton pectinatus and Ruppia spp. The most abundant fish are Mugil cephalus, Anguilla anguilla, Liza ramada, Gambusia affinis and Cyprinus carpio (Torralva et al. 2002). Poniente and Levante are used to store irrigation water and dried out completely in 1994, 1995 and 2003 (Reserva dried out in the same years). The inflow to Poniente and Levante contains organic matter and contaminants from the polluted Segura river and from agricultural and urban areas (Viñals et al. 2001). The inflow to Reserva is from agricultural areas.

The neighbouring Salinas de Santa Pola $\left(38^{\circ} 11^{\prime} \mathrm{N}\right.$, $00^{\circ} 38^{\prime} \mathrm{W}$ ) is a complex of 550 ha (not including c. 2000 ha of active solar saltworks). We studied three ponds (Múrtulas, Fig. 1) surrounded by Juncus, Carex, saltmarsh vegetation, Scirpus litoralis and $P$. australis. The dominant submerged macrophytes were Ruppia

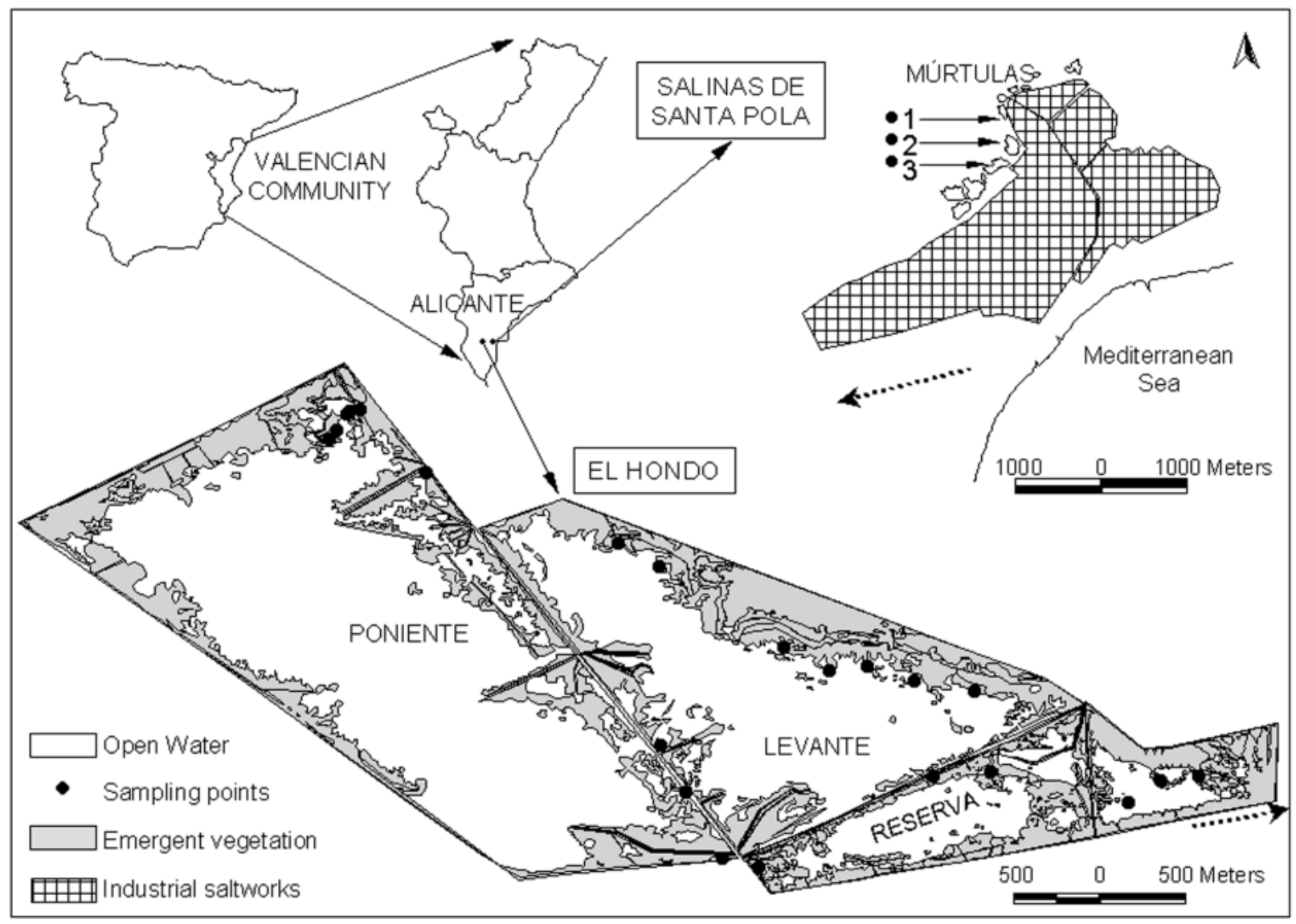

Fig. 1. Map of the study site showing the location of sampling points in El Hondo (Levante, Poniente and Reserva) and Salinas de Santa Pola (Múrtulas, 1 three sampling points, 2 two points, 3 one point). The two wetland complexes are $8 \mathrm{~km}$ apart and connected by the Dalt canal (dotted line). 
Table 1. Characteristics of the study sites and the points sampled. Secchi disk depth $=$ range observed over the study period (Múrtulas was too shallow to measure but had the clearest water). For depth at sampling points, conductivity and temperature at $5 \mathrm{~cm}$ depth, SS (suspended solids) and Chlorophyll $a$ we present mean \pm s.d. and the range observed (in parentheses) over the study period. Suspended solids and Chlorophyll a were measured on a roughly monthly basis by the Comunidad de Regantes del Hondo (unpublished data).

\begin{tabular}{lcccc}
\hline & Poniente & Levante & Reserva & Múrtulas \\
\hline Surface area (ha) & 625 & 405 & 185 & 7 \\
Maximum depth $(\mathrm{cm})$ & 250 & 150 & 100 & 50 \\
Secchi depth $(\mathrm{cm})$ & $3-56$ & $6-58$ & $4-52$ & - \\
Depth $(\mathrm{cm})$ & $32.6 \pm 17.9(1-71)$ & $39.2 \pm 17.1(2-70)$ & $27.2 \pm 15.4(0.01-65)$ & $14.7 \pm 10.0(0.01-32)$ \\
Conductivity $\left(\mathrm{mS} \mathrm{cm}^{-1}\right)$ & $9.6 \pm 3.8(6.2-33.0)$ & $9.5 \pm 3.5(6.2-20.5)$ & $16.6 \pm 6.2(10.6-54.4)$ & $17.3 \pm 3.4(13.0-24.7)$ \\
Temperature $\left({ }^{\circ} \mathrm{C}\right)$ & $19.7 \pm 5.9(6.9-32.1)$ & $19.6 \pm 6.9(6.1-31.9)$ & $18.5 \pm 6.1(4.0-33.6)$ & $21.6 \pm 5.9(11.5-30.7)$ \\
SS (mg $\left.{ }^{-1}\right)$ & $42.5 \pm 19.5(4-69)$ & $33.3 \pm 12.3(5-49)$ & $42.6 \pm 15.0(6-73)$ & - \\
Chlorophyll $a\left(\mu \mathrm{g} \mathrm{l}^{-1}\right)$ & $105 \pm 151(2.8-532)$ & $43.7 \pm 39.1(7.1-140)$ & $28.7 \pm 23.3(6-98.5)$ & - \\
\hline \hline
\end{tabular}

cirrhosa and P. pectinatus. Fish include Aphaenius iberus, Atherina boyeri, G. affinis and Pomatoschistus microps (Torralva et al. 2002). The inflow is from agricultural areas. These ponds were formerly part of a saltworks abandoned in 1979 (Marín \& Giovanni 1997). They are smaller, shallower and had a higher conductivity than the other study sites (Table 1), and the sediments contain more sand and less silt. Rodrigo \& Colom (1999) reported high nitrate concentration $\left(105 \mathrm{mgN}^{-1}\right)$ and a low chlorophyll $a$ concentration (3 $\mu \mathrm{g} \mathrm{l}^{-1}$, date of sampling not reported) for Múrtulas.

\section{Microcrustacean Sampling}

Levante, Poniente and Reserva were sampled monthly from February 1999 to June 2000, with the exception that Reserva was not sampled in October 1999. Múrtulas was sampled monthly from March to September 1999. Eight permanent sampling points were established at Levante and Poniente and six at Reserva and Múrtulas. These points were concentrated around the edges in the larger sites, in order to facilitate access. Each month, one sample was taken from each point. We randomly changed the precise spot where the sample was taken each month, to prevent disturbance effects. Owing to water level fluctuations, some points dried out at times, varying our sample size between months.

Depth was measured at each sampling point together with conductivity and temperature (with a Crison 524 meter) and turbidity (with a secchi disk). The sample was taken by vertically inserting a PVC tube of $16 \mathrm{~cm}$ internal diameter so as to sample from the water surfa- ce to a depth of $30 \mathrm{~cm}$, or to the bottom where depth was $<30 \mathrm{~cm}$. A net with $0.1 \mathrm{~mm}$ mesh was placed just below the position to be occupied by the base of the column. The column was then inserted and the water within was filtered through the net by lifting the column and net together vertically to the water surface. This sampling methodology was chosen owing to our interest in establishing the availability of invertebrate prey to waterbirds which concentrate their feeding within the top $30 \mathrm{~cm}$ of the water column (see also Cooper \& Anderson 1996).

Each sample from a given point was stored in $70 \%$ ethanol and later washed in the laboratory at Alicante University in a $0.3 \mathrm{~mm}$ sieve to remove sediments and meiofauna, and the zooplankton retained were stored in $70 \%$ ethanol. Cladocera, Copepoda and Ostracoda were later separated and counted at Doñana Biological Station, and their volume (an approximate measure of fresh biomass) was quantified by displacement. In samples with large numbers, we subsampled by placing the sample in a scored petri dish and counting the number of individuals (including juveniles) in divisions chosen at random. The Cladocera species present in each sample were identified at Granada University using Alonso (1996) and Scourfield \& Harding (1994).

\section{Statistical analysis}

To test the effects of month, site and other predictors in explaining presence (1) or absence (0) of Cladocera in samples, we used a class of Generalized Linear Models (GLMs) known as logistic regression (McCullagh \& Nelder 1989, Crawley 1993), fitting models with a 
binomial error function and a logit link. We carried out generalized linear mixed models (see Herrera 2000) using the GLIMMIX macro in SAS (SAS Institute 1996), incorporating month and site as fixed factors, and including a random factor coding for each sampling point. By incorporating the random factor, these mixed models allowed us to control for differences between sampling points, and to make allowances for the changes in numbers of points between months (e.g. due to points drying out). We controlled for the height of the water column sampled (adding a continuous predictor variable to the model) since the larger the volume, the more likely a randomly distributed invertebrate is to be recorded. Post-hoc differences between individual pairs of sites were tested with the Wald chisquare test for differences between least-squares means (SAS Institute Inc. 1997). We first analyzed the data for the three El Hondo wetlands taken during 17 months, then repeated our analyses for the seven months with data for all four sites including Múrtulas.

We then analyzed the density (number of individuals per litre) of cladocerans in the samples (excluding zero counts) with GLMs using a gamma error distribution and a log link function (Crawley 1993), using the GLIMMIX macro in SAS. We then added depth and conductivity to these models to test the partial effects of these variables within a given site and month, using models with a reduced dataset due to changes in the amount of missing data (e.g. owing to problems with the conductivity meter).

\section{Results}

Water levels underwent major fluctuations at the El Hondo wetlands (Figure 2), owing largely to irrigation activities. Temperature and conductivity showed considerable seasonal variation, and both tended to peak in July-August (Figure 3). Conductivity showed a strong partial correlation with depth $(\mathrm{r}=-0.45$, df $=$ $298, \mathrm{P}<0.001$ ) while controlling for site and month.

In terms of biomass, the microcrustacean community was dominated by cladocerans at Poniente and Levante, by copepods at Reserva, and by ostracods at Múrtulas (Figure 4). Numbers of Cladocera recorded were much higher at Levante and Poniente, and extremely small at Múrtulas (Fig. 5). Numbers of cladocerans peaked in spring, from March to May, with a second peak in September at Poniente (Fig. 5).

Five cladoceran species were recorded (Table 2), with maximum species richness in spring (when abundance was highest) and minimum richness in summer (when abundance was lowest). In summer, only Daphnia magna was recorded (Table 2). Poniente held the most species (all five), while Múrtulas held the least (two). Levante held four species and Reserva three. $D$. magna and D. pulex were recorded at all four sites, whereas D. longispina, Simocephalus exspinosus and Moina brachiata were recorded at two sites each (Table 2). D. magna was the most abundant species and the only one recorded all year round. $D$. pulex was the only other species recorded in more than two seasons (Table 2).

Logistic regression showed that there were signifi-

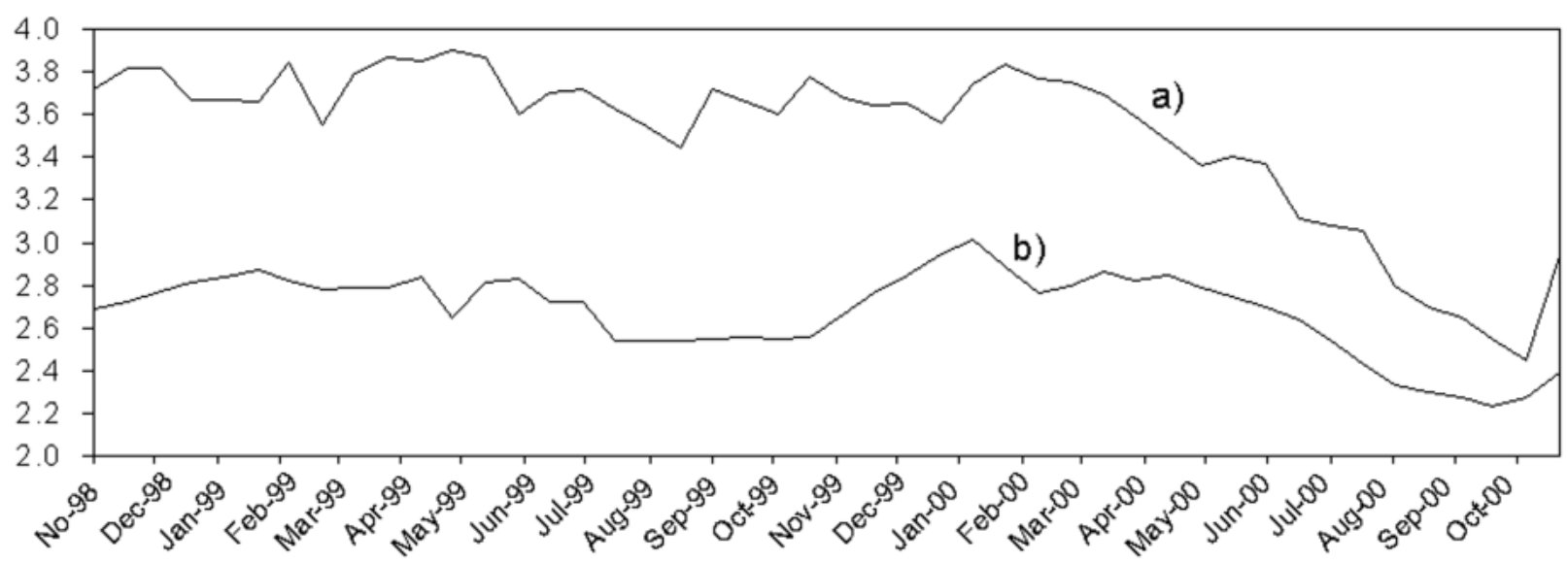

Fig. 2. Fluctuation in water levels (m) recorded at a) PON and LEV, b) RES during our study period. The vertical scale refers to the depth in peripheral canals and exceeds that found in the lakes themselves. 

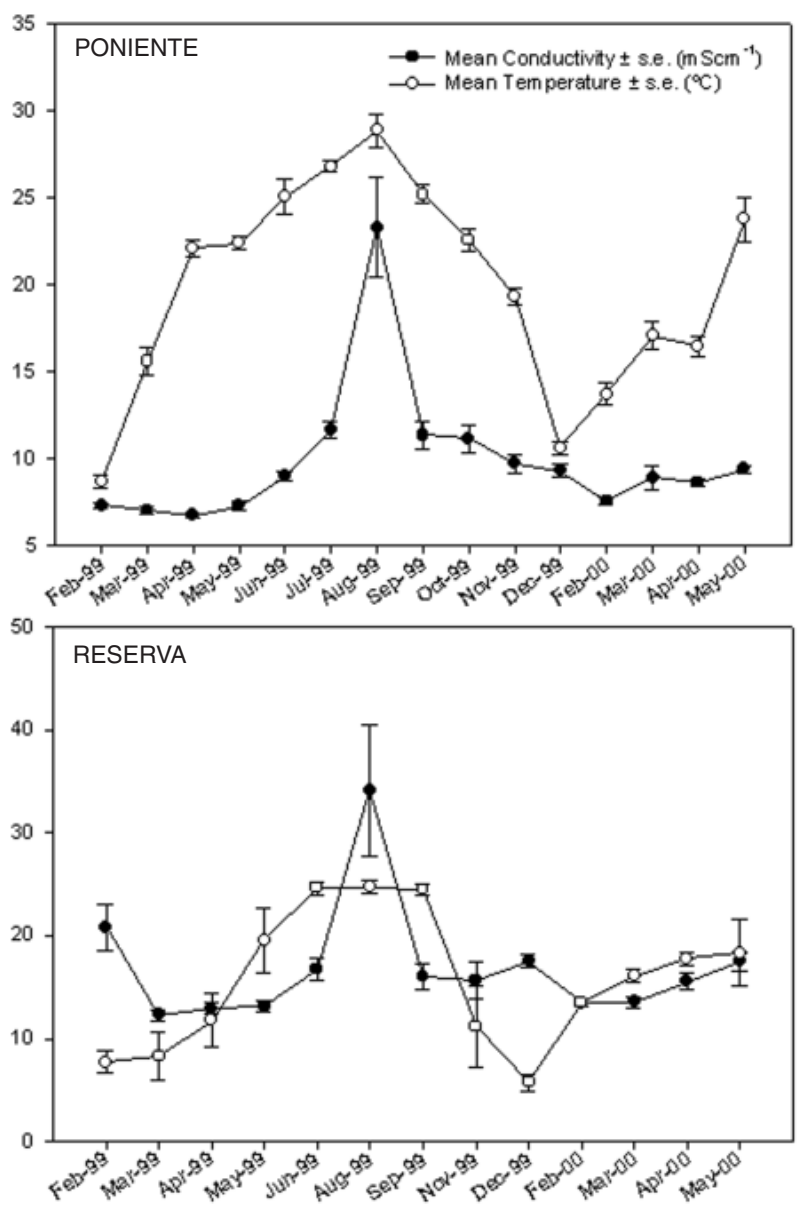

cant differences between the three El Hondo wetlands $\left(\mathrm{F}_{2,275}=23.59, \mathrm{P}<0.0001\right)$ and between months $\left(\mathrm{F}_{15,275}=3.27, \mathrm{P}<0.0001\right)$ in the probability of presence of Cladocera in the samples. Post-hoc tests showed that presence of Cladocera was significantly lower at Reserva than at the other two sites, and significantly lower at Poniente than at Levante. Similar logistic models incorporating Múrtulas for the seven months when all four sites were sampled showed significant differences between the four wetlands in the presence/absence of Cladocera $\left(\mathrm{F}_{3,142}=10.4, \mathrm{P}<\right.$ 0.0001). Post-hoc tests showed that presence of Cladocera was significantly lower at Murtulas and Reserva than the other two sites, and significantly lower at Poniente than Levante.

Models of the density of cladocerans (number of individuals $\mathrm{1}^{-1}$ ) in the El Hondo wetlands showed significant differences between months $\left(\mathrm{F}_{15,156}=7.86, \mathrm{P}<\right.$ $0.0001)$ and sites $\left(\mathrm{F}_{2,156}=12.78, \mathrm{P}<0.0001\right)$. Post-

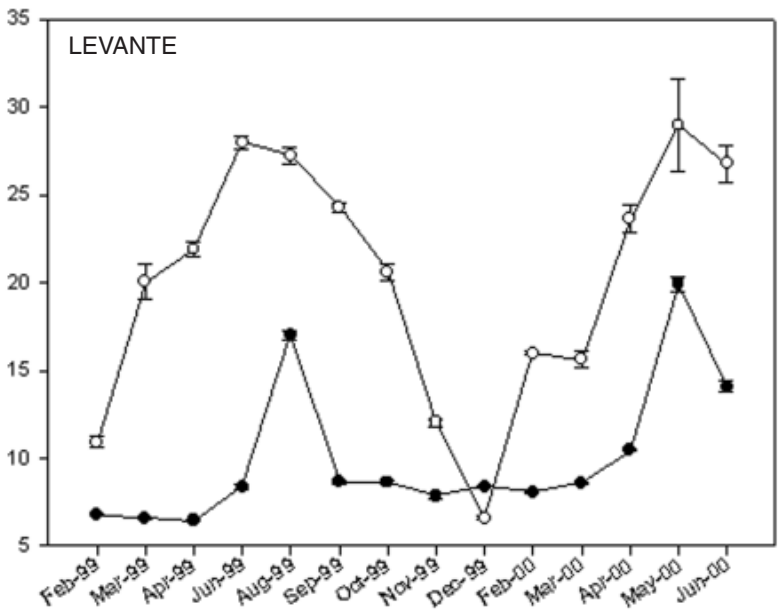

Fig. 3. Fluctuation in conductivity and water temperature recorded at each wetland during our study period, showing mean \pm s.e. for a given month.

hoc tests showed that Reserva held significantly lower densities than the other two sites. Similar models for the seven months including Múrtulas showed significant differences in density between the four wetlands $\left(F_{3,48}=19.36, P<0.0001\right)$. Post-hoc tests showed that density was significantly lower at Murtulas and Reserva than at the other two sites, and significantly lower at Levante than at Poniente.

While controlling for month, site and depth of sampling point at El Hondo, conductivity had a significant, negative partial correlation on the density of cladocerans $\left(F_{1,127}=7.28, P<0.01\right)$. Similarly, while controlling for month, site and conductivity at El Hondo, depth of sampling point had a significant, positive partial correlation on the density of cladocerans $\left(\mathrm{F}_{1,127}=\right.$ $30.95, \mathrm{P}<0.0001)$.

\section{Discussion}

Ours is the first study of zooplankton in Poniente, Levante (the most important wetlands in El Hondo) and Múrtulas, although Armengol et al. (2002) conducted an earlier study at Reserva (called by them the Charca Sureste) in which they found no Cladocera. Poniente and Levante were dry in 1994-1995 at the time of the study by Armengol et al. (2002). The cladoceran community we have recorded is what has been described as the «Daphnia magna association» for a total of 13 mesosaline steppe wetlands in Mediterranean Spain (Alonso 1998). Not surprisingly given the 

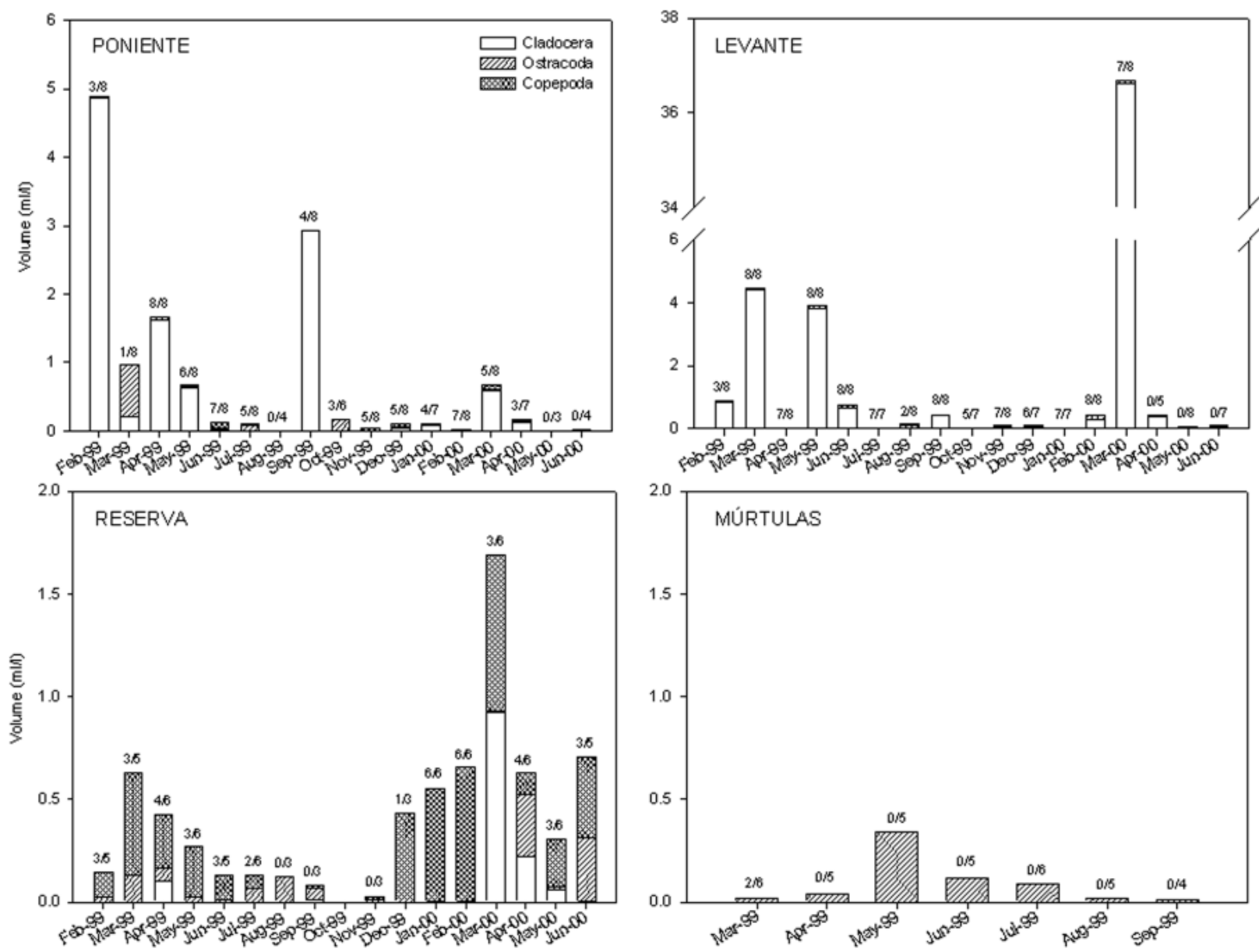

Fig. 4. Volumetric density ( $\mathrm{ml}$ invertebrates per litre of sample, showing mean values for all samples) in each month at each wetland for microcrustacea in the water column (Cladocera, Ostracoda and Copepoda). Above each column is listed the total number of points sampled and used for analysis each month (second number) and the number at depths $>30 \mathrm{~cm}$ (first number). No samples were taken in October 99 at Reserva. Note the change in scale on the y axis.

salinities observed during our study, the euryhaline species D. magna and D. pulex were dominant, whereas $M$. brachiata (a species characteristic of lower salinities, Alonso 1998) and S. exspinosus were rarer. The latter species were only observed in winter and spring, when salinities and temperature were at their lowest. D. longispina is widely distributed in Spain, but is more often observed at lower salinities and (as in our study) in winter and spring (Armengol 1978, Alonso 1996). We did not record Simocephalus vetulus, a species reported from El Hondo in the 1980s (Miracle and Alfonso pers. comm. to Armengol et al. 2002). D. magna is the only species we observed all year round, because it is polycyclical and particularly tolerant of high salinities (Alonso 1990, 1998).

The largest and deepest sites Poniente and Levante had the highest densities of Cladocera. The smallest, shallowest and most saline site Múrtulas had the lowest density of Cladocera. Our results within wetlands suggest that the differences in relative abundance among lakes in Cladocera are largely explained by both salinity and depth differences. We found the density of cladocerans at a given site and date to decrease with increasing conductivity. This suggests that they are intolerant of the higher salinities found in some parts of our study wetlands. We also found the density of Cladocera at a given site and date to increase with increasing depth. 

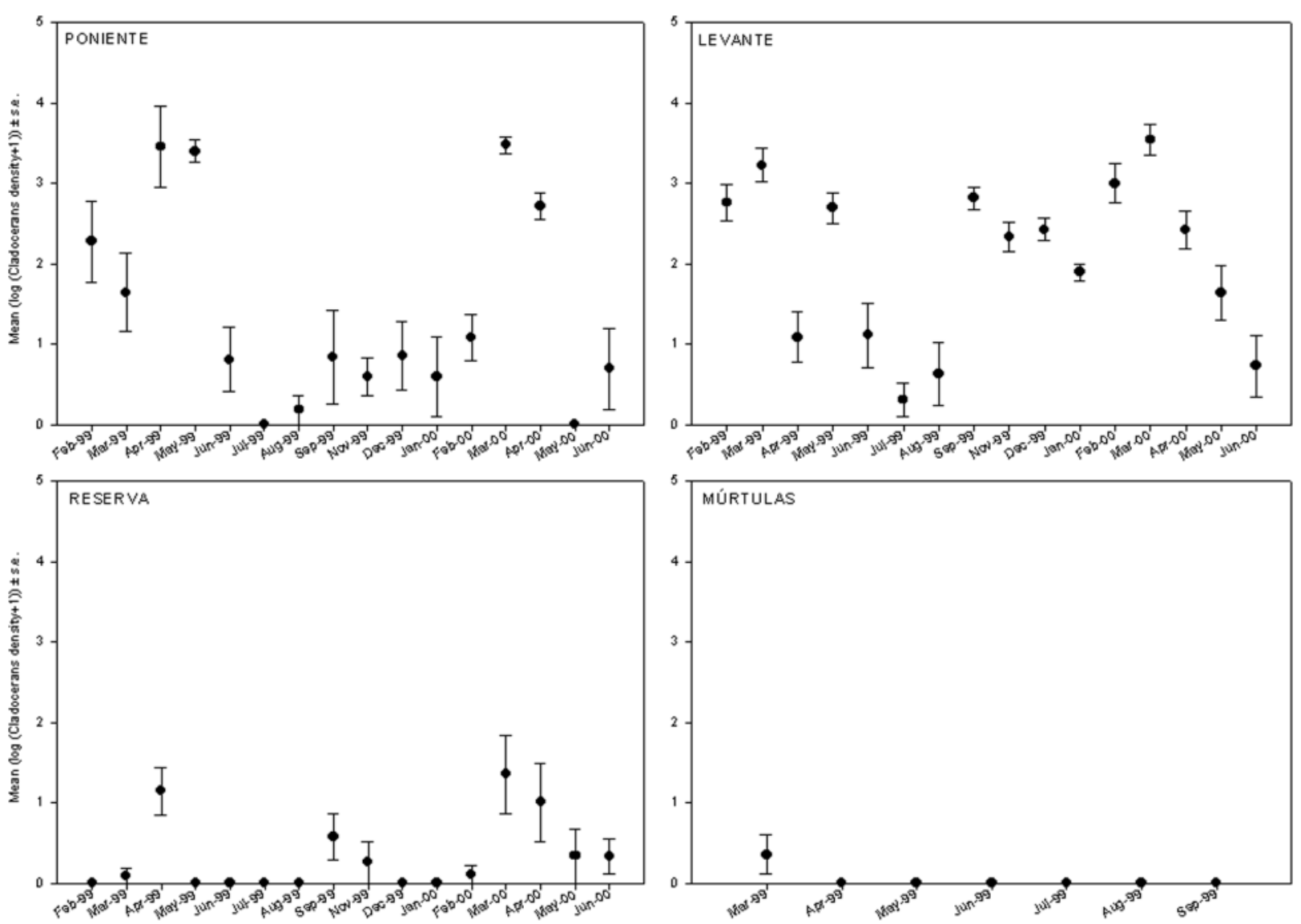

Fig. 5. Density of cladocera (number per litre of sample, $\log 10$ transformed, showing mean \pm s.e.) in each month at each wetland.

Table 2. Spatial and temporal distribution of Cladocera species in the study sites. $\mathrm{P}=$ Poniente, $\mathrm{L}=$ Levante, $\mathrm{R}=\mathrm{Reserva}$, $\mathrm{M}=$ Múrtulas. $\mathrm{PO}=$ Percentage of occurrence of each taxon in samples with Cladocera $(\mathrm{N}=62)$.

\begin{tabular}{lccccc}
\hline \multicolumn{1}{c}{ SPECIES } & SPRING & SUMMER & AUTUMN & WINTER & PO \\
& Mar-May & Jun-Aug & Sep-Nov & Dec-Feb & PO \\
\hline Daphnia (Ctenodaphnia) magna Straus & PLRM & PLR & PLR & PL & 75.8 \\
Daphnia (Daphnia) pulex DeGeer & PLRM & - & L & L & 24.2 \\
Daphnia (Daphnia) longispina Müller & PL & - & - & L & 8.1 \\
Simocephalus exspinosus DeGeer & P & - & - & PL & 17.7 \\
Moina brachiata Jurine & PR & - & - & - & 9.7 \\
\hline
\end{tabular}

Reproductive and/or survival rates of cladocerans are generally reduced at higher conductivities (Galat \& Robinson 1983). A decrease in the relative abundance of cladocerans in microcrustacean zooplankton as sali- nity increases has been observed in many aquatic systems (Hurlbert et al. 1986, Kingsford \& Porter 1994, Moss 1994, Wollheim \& Lovvorn 1995, Bolduc \& Afton 2003). The lower species richness of Cladocera we 
observed in Reserva and Múrtulas was probably related to their high salinities. Increasing salinity is known to have a negative effect on species richness for Cladocera (Hobæk et al. 2002). The decline we observed in species richness in summer may be associated with the high salinities and temperatures at this time, or perhaps with cyanobacteria blooms.

The low cladoceran species richness we recorded is rather similar to that observed in other Spanish wetlands with a similar salinity. In 170 wetlands with salinities overlapping with those recorded at our study sites (most of which had waterbird densities far below those recorded here), Alonso (1998) recorded from 0 to 8 cladoceran species (mean \pm s.d. $=2.9 \pm 1.7$ ). The low cladoceran species richness we observed was not a consequence of our unusual sampling methods or our failure to sample the centre of the larger wetlands. Armengol et al. (2002) used different methods and found no cladocerans in any part of Reserva. D. magna was the only species recorded in separate samples we took with a plankton net in the centre of Poniente and Reserva in June 1998. The diversity of other microcrustacean groups recorded in these wetlands is also relatively low, with only six species of copepods (Rodrigo et al. 2001).

El Hondo is one of the ten most important wetlands in Spain in terms of numbers of migratory waterbirds (Martí \& del Moral 2002). The international importance of El Hondo for a high number of waterbird species, many of which are threatened (Martí \& del Moral 2002,2003 ) is not associated with a similar importance for Cladocera. El Hondo and Santa Pola are characterised by an extremely low number of cladoceran species, all of which are subcosmopolitan and of low conservation concern. This suggests that diversity of aquatic birds is not a good indicator of diversity of other aquatic organisms such as Cladocera (see also Green et al. 2002). The existing network of protected wetlands in Europe and the Mediterranean region has a strong ornithocentric bias and seems unlikely to provide adequate coverage for microcrustacea. Specific measures are required to ensure that hotspots of crustacean diversity are identified and protected.

Given the large number of migratory birds visiting the area and their capacity to transport ephippia internally (Figuerola et al. 2003) and externally (Figuerola \& Green 2002b), dispersal limitation can not explain the low species richness of Cladocera at El Hondo. Cladoceran ephippia are abundant in the faeces of migratory ducks from El Hondo (Fuentes et al. 2004). The Shoveller, the most abundant and most planktivorous waterbird at El Hondo, concentrated at Levante and Poniente during our study where Cladocera were most abundant. Shoveller are better dispersers of ephippia than other ducks in Spain (Figuerola et al. 2003), and come to El Hondo from wetlands all over northern Europe (Navarro 1988). Hence cladoceran species richness must be limited by local conditions such as salinity, fish density or water quality, which prevent establishment of immigrant species arriving via birds.

Although differences in fish densities are also likely to influence the relative abundance of Cladocera (Hurlbert et al. 1986, Jeppesen et al. 1997), we have no data on fish densities for our study period. Blooms of cyanobacteria can also lead to declines in cladoceran populations (Jeppesen et al. 1997), and such blooms occur at El Hondo (Barba et al. 2004, E. Costas, pers. comm.). Cladocerans are particularly sensitive to organochlorine pesticides (Stansfield et al. 1989) and it is also possible that cladocerans are negatively affected by pesticides in the water supplying El Hondo.

\section{Acknowledgements}

P. Cervera, M.M. Delgado, D. Liñana, M. Macias, G. Martín, M. Ferrández, J.L. Echevarrias, V. Levassor, P. Corbacho, K. Schwenk and staff from El Hondo and Salinas de Santa Pola Natural Parks helped to collect, quantify and identify the samples. The Consellería de Medio Ambiente, Generalitat Valenciana provided data on suspended solids and chlorophyll concentration and funded our work as part of an EU LIFE project. Four anonymous referees helped us to improve the manuscript.

\section{References}

Alonso M. 1990. - Anostraca, Cladocera and Copepoda of Spanish saline lakes. Hydrobiologia, 197, 221-231.

Alonso M. 1996. - Crustacea Branchiopoda. Serie Fauna Ibérica, Vol. 7. CSIC. 486 pp. Madrid.

Alonso M. 1998. - Las lagunas de la España peninsular. Limnetica, $15,1-176$

Armengol J. 1978. - Zooplankton crustaceans in Spanish reservoirs. Ver. Internat. Verein. Limnol., 20,1652-1656.

Armengol-Díaz X., Rodrigo M.A. \& Oltra R. 2002. - Caracterizacilon del zooplancton de la zona sur del Parque Natural del Hondo (Alicante). Ecología, 16, 243-257.

Barba E., Armengol J., Atiénzar F. \& Larrosa J. 2004. - Estudio del uso del hábitat de la malvasía cabeciblanca en la Comunidad Valenciana. Valencia : Conselleria de Territori i Habitatge.

Bernués M. (ed.). 1998. - Humedales Españoles inscritos en la Lista del Convenio de Ramsar. Ministerio de Medio Ambiente, Organismo Autónomo de Parques Nacionales, Madrid.

Bolduc F. \& Afton A.D. 2003. - Effects of structural marsh management and salinity on invertebrate prey of waterbirds in marsh ponds during winter on the Gulf Coast Chenier Plain. Wetlands, 23, 897-910.

Cirujano S., Medina L., Peris J.B., \& Stübing G. 1995. - Estudio de la flora y vegetación de los Parajes Naturales de las Salinas de Santa Pola, El Hondo y las Lagunas de la Mata y Torrevieja. Unpublished report.

Cooper C.B. \& Anderson S.H. 1996. - Significance of invertebrate 
abundance to dabbling duck brood use of created wetlands. Wetlands, 16, 557-563.

Crawley M.J. 1993. - GLIM for Ecologist, Blackwell Scientific Publications, Cambridge.

Figuerola J. \& Green A.J. 2002a. - Dispersal of aquatic organisms by waterbirds : a review of past research and priorities for future studies. Freshwat. Biol., 47, 483-494.

Figuerola J. \& Green A.J. 2002b. - How frequent is external transport of seeds and invertebrate eggs by waterbirds? A study in Donana, SW Spain. Archiv Hydrobiol., 155, 557-565.

Figuerola J., Green A.J. \& Santamaria L. 2003. - Passive internal transport of aquatic organisms by waterfowl in Doñana, southwest Spain. Global Ecol. Biogeogr., 12, 427-436.

Fuentes C., Sanchez M. I., Selva N. \& Green A.J. 2004. - The diet of the Marbled Teal Marmaronetta angustirostris in southern Alicante, eastern Spain. Rev. Ecol., 59, 475-490.

Galat D.L. \& Robinson R. 1983. - Predicted effects of increasing salinity on the crustacean zooplankton community of Pyramid Lake, Nevada. Hydrobiologia, 105, 115-131.

Green A.J., El Hamzaoui M., El Agbani M.A. \& Franchimont J. 2002. - The conservation status of Moroccan wetlands with particular reference to waterbirds and to changes since 1978. Biol. Conserv., 104, 71-82

Green A.J. \& Figuerola J. 2005. - Recent advances in the study of long-distance dispersal of aquatic invertebrates via birds. Divers. Distrib., 11, 149-156.

Herrera C.M. 2000. - Flower-to-seedling consequences of different pollination regimes in an insect-pollinated shrub. Ecology, 81, 15-

Hobæk A., Manca M. \& Andersen T. 2002. - Factors influencing species richness in lacustrine zooplankton. Acta Oecol., 23, 155163.

Hurlbert S. H., Loayza W. \& Moreno T. 1986. - Fish-flamingoplankton interactions in the Peruvian Andes. Limnol. Oceanogr. 31, 457-468.

Jeppesen E., Jensen J.P., Sondergaard M., Lauridsen T., Pedersen L.J. \& Jensen L. 1997. - Top-down control in freshwater lakes The role of nutrient state, submerged macrophytes and water depth. Hydrobiologia, 342, 151-164.

Kingsford R.T. \& Porter J.L. 1994. - Waterbirds on an adjacent freshwater lake and salt lake in arid Australia. Biol. Conserv., 69 219-228.

Marín C. \& Giovanni P. 1997. - Nature and workmanship. Artificial wetlands in the Mediterranean coast. International Scientific Council for Island Development, Paris.
Martí R. \& del Moral J.C. (eds.). 2002. - La invernada de aves acuáticas en España. Dirección General de la Naturaleza-SEO/BirdLife, Organismo Autónomo Parques Nacionales, Ministerio de Medio Ambiente, Madrid.

Martí R. \& del Moral J.C. (eds.). 2003. - Atlas de las Aves Reproductoras de España. Dirección General de Conservación de la Naturaleza y Sociedad Española de Ornitología. Madrid.

McCullagh P. \& Nelder J.A. 1989. - Generalized Linear Models, $2^{\text {nd }}$ edn. Chapman and Hall, London.

Moss B. 1994. - Brackish and Fresh-Water Shallow Lakes - Different Systems or Variations on the Same Theme. Hydrobiologia 276, 1-14.

Navarro J.D. 1988. - Estudio ornitológico de «El Hondo». Alicante Caja de Ahorros del Mediterráneo.

Rodrigo M.A., Armengol-Díaz X., Oltra R., Dasí M.J., \& Colom W. 2001. - Environmental variables and planktonic communities in two ponds of El Hondo wetland (SE Spain). Int. Rev. Hydrobiol. 86, 299-315.

Rodrigo M.A. \& Colom W. 1999. - Limnología de los humedales valencianos susceptibles de albergar Samaruc y Fartet : (I) físicoquímica. Pages 59-77 in Peces ciprinodóntidos ibéricas Fartet y Samaruc (Ed. Ambiente; C.d.M.), Valencia: Generalitat Valenciana.

SAS Institute Inc. 1996. - SAS System for Mixed Models. Cary, NC

SAS Institute Inc. 1997. - SAS/STAT ${ }^{\circledR}$ Software, changes and enhancements through Release 6.12. Cary, NC.

Scourfield D.J \& Harding J.P. 1994. - British freshwater cladocera. A key. Scientific Publication Vol. 5. Freshwater Biological Association. Ambleside (UK)

Stansfield J., Moss B. \& Irvine K. 1989. - The loss of submerged plants with eutrophication .3. Potential role of organochlorine pesticides - a paleoecological study. Freshwat. Biol., 22, 109-132.

Torralva M., Oliva-Paterna F.J., Miñano P.A., Andreu A., Caballero A., Egea A. \& Verdiell D. 2002. - Estudio de la situación de las carpas (Cyprinus carpio) y su efecto sobre la malvasía cabeciblanca (Oxyura leucocephala) en el Parque Natural El Hondo: componente ictiofaunístico. Valencia : Conselleria de Medi Ambient.

Viñals M.J., Colom W., Rodrigo T., Dasi M.J., Armengol J., Oltra R. \& Miracle R. 2001. - Rasgos característicos de un humedal mediterráneo artificializado y su problemática ambiental : El Hondo de Elche (Alicante, España). Humedales Mediterráneos, 1,147-154.

Wollheim W.M. \& Lovvorn J.R. 1995. - Salinity effects on macroinvertebrate assemblages and waterbird food webs in shallow lakes of the Wyoming High Plains. Hydrobiologia, 310, 207-223. 